\title{
Effects of forest structure components on the occurence, group size and density of groups of bare-face tamarin (Saguinus bicolor - Primates: Callitrichinae) in Central Amazonia
}

\author{
Marcelo Derzi VIDAL ${ }^{1}$, Renato CINTRA ${ }^{2}$
}

\begin{abstract}
This study analyzed the influence of forest structural components on the occurence, size and density of groups of Bare-face Tamarin (Saguinus bicolor) - the most threatened species in the Amazon - and produced the first map of distribution of groups in large-scale spatial within the area of continuous forest. Population censuses were conducted between November 2002 and July 2003, covering 6400 hectares in the Ducke Reserve, Manaus-AM, Brazil. Groups of $S$. bicolor were recorded 41 times accordingly distributed in the environments: plateau (20); slopes (12); and lowlands (09). The mean group size was 4.8 indiv./group, and ranged from 2 to 11 individuals. In the sites where the groups were recorded, and in an equivalent number of sites where no tamarins were found located at least $500 \mathrm{~m}$ from those where they had been recorded, we placed $50 \mathrm{~m} \times 50 \mathrm{~m}$ plots to record the following forest structural components: abundance of trees; abundance of lianas; abundance of fruiting trees and lianas; abundance of snags; abundance of logs; percentage of canopy opening; leaf litter depth; and altitude. Bare-face Tamarin more often uses areas with lower abundance of forest logs, smaller canopy opening and with higher abundance of snags, areas in the forest with smaller canopy opening present higher density of S. bicolor groups. Apparently this species does not use the forest in a random way, and may select areas for its daily activities depending on the micro-environmental heterogeneity produced by the forest structural components.
\end{abstract}

KEY WORDS

Saguinus bicolor, population, ecology, Ducke Reserve, threatened species.

\section{Efeito dos componentes estruturais da floresta na ocorrência, tamanho e densidade de grupos do sauim-de-coleira (Saguinus bicolor - Primates: Callitrichinae), na Amazônia Central}

\begin{abstract}
RESUMO
Este estudo analisou a influência de componentes estruturais da floresta na ocorrência, tamanho e densidade de grupos do Sauim-de-coleira (Saguinus bicolor) - a espécie de primata mais ameaçada na Amazônia-e produziu o primeiro mapa de distribuição de grupos em grande escala espacial dentro de uma área continua de floresta. Censos populacionais foram conduzidos entre novembro de 2002 e julho de 2003, cobrindo 6400 hectares na Reserva Ducke, Manaus-AM, Brasil. Quarenta e um grupos de sauins foram registrados conforme os ambientes: platô (20), vertente (12), e baixio (09). O número de indivíduos por grupo variou de 2 a 11, com uma média de 4,8 indivíduos/grupo. Nos locais onde os grupos foram registrados, e em um número equivalente onde não ocorreram, localizados a pelo menos 500 m daqueles locais onde eles ocorreram, colocamos parcelas de $50 \mathrm{~m} \times 50 \mathrm{~m}$ para registrar os seguintes componentes de estrutura da floresta: abundância de árvores, abundância de lianas, abundância de árvores e lianas frutificando, abundância de troncos mortos em pé, abundância de troncos mortos no chão, percentagem de abertura do dossel, profundidade do folhiço, e altitude. O sauim-de-coleira usou mais freqüentemente áreas com menor abundância de troncos mortos no chão, menor abertura do dossel, e com maior abundância de troncos mortos em pé. Áreas com menor abertura do dossel apresentaram maiores densidades de grupos de sauím-de-coleira. Aparentemente esta espécie não usa a floresta ao acaso, e deve selecionar áreas para as suas atividades diárias dependendo da heterogeneidade micro-ambiental produzida por componentes estruturais da floresta.
\end{abstract}

\section{PALAVRAS-CHAVE}

Saguinus bicolor, população, ecologia, Reserva Ducke, espécie ameaçada.

\footnotetext{
${ }^{1}$ Curso de Pós-graduação em Ecologia do INPA. Endereço atual: Instituto Brasileiro do Meio Ambiente e dos Recursos Naturais Renováveis - Ibama. Projeto Manejo dos Recursos Naturais da Várzea - ProVárzea. Rua Ministro João Gonçalves de Souza, s/n, Distrito Industrial, 69075-830, Manaus - AM. E-mail: mderzi@provarzea.ibama.gov.br

${ }^{2}$ Instituto Nacional de Pesquisas da Amazônia - INPA. Departamento de Ecologia. Caixa postal 478, 69011-970, Manaus -AM. E-mail: cintra@inpa.gov.br
} 


\section{INTRODUCTION}

The use of habitat by primates can be affected by many factors such as body size, dietary adaptations, changes in forest structure and local weather conditions (Ferrari, 1988). The spatial variation of the forest resources certainly stimulates their use in different ways, and may produce changes in the primate patterns of movement and habitat use.

Intra-specific variations in habitat use by primates can be associated with spatial and temporal variations in resources such as food, water availability, or local forest structure that provides an appropriate environment for daily needs and activities (Oates, 1987; Rylands, 1986).

Soils poor in nutrients, with a thin layer of organic matter, and low floristic heterogeneity among different habitats, can also contribute to the low density of primates (Peres, 1991). The terra firme forests around Manaus have low primate biomass and density, probably due to the extremely poor nutrient concentrations from the yellow latossols in the region (Peres, 1993; Spironello, 2001).

It has been suggested that primates from the family Callitrichinae prefer to use secondary forests and areas with dense shrubs, primary forest borders, and especially open areas in mature forest (Goldizen, 1987; Terborgh, 1983). Among other things, these preferences are generally explained by: 1) the tamarins' dietary habits - mainly insectivorous-frugivorous; 2 ) the relatively high insect abundance in the secondary vegetation, and 3) the higher abundance of the very attractive fruiting pioneer trees (Mittermeier \& van Roosmalen, 1981; Terborgh, 1983; Yoneda, 1984).

However, other studies have shown that tamarins use all kinds of habitats available in areas of secondary and primary forest (Ferrari, 1993; Rylands \& Faria, 1993). For example, the tamarin (Leontopithecus chrysopygus) is a food generalist, and uses different forest types (Pádua, 1993). In the Amazon forest, the species Saguinus fuscicollis and $S$. mystax use all of them: the mature forest with tall trees, forests dominated by palms, lowland areas, and also Igapó forests (Peres, 1993).

In most of the areas where they occur, Saguinus bicolor use a mosaic of vegetation, including mature and secondary forest, campinas and campinaranas). They use forest with tall trees mostly during the wet season, and secondary forest (capoeira) during the dry season (Egler, 1986; Subirá, 1998).

Its co-generic species, the Saguinus midas, also occurs in all habitats, from those in forest borders to those in forest interiors, but seems to prefer liana forests (Mittermeier \& van Roosmalen, 1981).

The presence of lianas also seems to be important because areas with clumps of lianas are often used by tamarins as roosting spots. Saguinus, Cebuella, and Callithrix, use branches with clumps of lianas more often and occasionally sleep in tree trunk holes (Stevenson \& Rylands, 1988), but Leontopithecus are perhaps a unique tamarin species, using tree holes for daily roosting activities.

Some authors believe that food availability is the main factor affecting habitat use by animals, with their home range being related to the animals' energetic needs as well as the carrying capacity of the environments they use (McNab, 1983; Oates, 1987). Although all tamarins eat fruits, earlier studies have indicated that Saguinus is more frugivorous than other tamarins (Garber, 1993). The small amount of small fruits available for long periods and within some limited areas seems to be good for Saguinus, and they also feed on arthropods, nectar, flowers, gums, and small invertebrates (Egler, 1986; Garber, 1991; Terborgh, 1983).

In any forest environment, no matter what kind of structure it has, the spatial variation in leaf litter depth on the forest floor, and the abundance of forest snags, may also affect food availability for tamarins. Areas with more complex forest structure could be used for breeding and protection from predators, and for foraging on the large number of tamarin prey, such as insects and small vertebrates (Egler, 1986; Pádua, 1993; Tavares, 1999).

Although food and habitat availability are important for tamarins there is no information on how habitat heterogeneity produced by its own structural components, affects habitat use by small primates, principally in more complex environments such as those of tropical rainforests. In addition most of the studies available on tamarins were conducted, with few groups, and in relatively small spatial scale or areas with less than 100 hectares.

In this study, we evaluated how some forest structure components (abundance of trees; abundance of lianas; abundance of fruiting trees and lianas; abundance of snags; abundance of logs; percentage of canopy opening; leaf litter depth; and altitude) have affected the occurrence, number of individuals (group size) and density of groups of Bare-face tamarin (S. bicolor) in the Ducke Reserve. This may be the first ecological study undertaken with small primates on such a large spatial scale in the Amazon forest.

\section{METHODS}

\section{STUDY AREA}

The study was conducted in the Ducke Reserve, which is part of the Instituto Nacional de Pesquisas da Amazônia (INPA), near Manaus ( $02^{\circ} 55^{\prime}$ to $03^{\circ} 01^{\prime} \mathrm{S}$, 59 $59^{\prime}$ to $\left.59^{\circ} 59^{\prime} \mathrm{W}\right)$. The Reserve has an area of 10,000 hectares covered mainly by terra firme forest, and is still connected to the continuous forest on the eastern side.

In the years 2000 and 2001, a large trail grid was implemented and covering the entire area of the Reserve. The 
grid has eighteen $8 \mathrm{~km}$ trails, 9 oriented north-south and 9 oriented east-west, making a system of 64 squares of 1 x $1 \mathrm{~km}$. All trails were marked at $100 \mathrm{~m}$ intervals using PVC tubes.

The site has a gently rolling topography alternating with well-drained flat plateaus ( $140 \mathrm{~m}$ of altitude) and wet lowlands along forest streams (called baixios). The soils are acid and nutrient-poor on the plateaus, and mainly oxissols (old clay sediments) and sandy in the lowlands (Ribeiro et al. 1999). The local vegetation is mainly terra firme forest, with more than 1000 tree species occurring in the area, many reaching $30-37 \mathrm{~m}$ in height, and emergents over $40 \mathrm{~m}$ height (Ribeiro et al.1999).

\section{POPULATION SURVEYS OF Saguinus bicolor IN THE DUCKE RESERVE}

The surveys of tamarins covered the entire trail system of the Reserve. They were conducted during 8 days/month, between November 2002 and July 2003, totaling $720 \mathrm{~km}$ of surveys distributed uniformly over the trail system. During the same period, forest structure components were recorded during different 8-day periods each month.

The surveys were done from 06:30 to 11:30 am, and 01:00 to $04: 00 \mathrm{pm}$., finishing at the same time the tamarins finished their daily activities (Egler, 1986).

To maximize the chances of recording the tamarins, we walked along the trails at a speed of $1.5 \mathrm{~km} / \mathrm{h}$, stopping for 30 seconds every $50 \mathrm{~m}$ to visually search and listen for any tamarims within $50 \mathrm{~m}$ on both sides of the trail (Peres, 1997). Additional records were made off trails and during other times, however they were not used in the analysis.

At each spot where tamarins were recorded, we registered the following information: 1) day and time in which the tamarin was seen; 2) trail number and position along trail in which the tamarin group was seen; 3 ) number of tamarin individuals in the group; 4) behaviour (foraging, moving, resting, vocalizing); and 5) environment (plateau - between 110 and $140 \mathrm{~m}$ of altitude, slopes or sloping terrain - altitude ranging from 70 to $100 \mathrm{~m}$, lowlands or "baixios" - between 40 and $60 \mathrm{~m}$ of altitude).

\section{RECORDING THE FOREST STRUCTURE COMPONENTS}

In the same spots where tamarin groups were recorded, we established $50 \times 50 \mathrm{~m}$ plots, using $50 \mathrm{~m}$ metric tapes, to quantify the following forest structure components and features of the landscape: 1) the number of trees (Diameter at breast height $\mathrm{DBH}>10 \mathrm{~cm}), 2$ ) the number of lianas 3) the number of logs, 4) the number of forest standing dead trees (snags), 5) the number of fruiting trees and fruiting lianas; 6) the leaf litter depth; 7) the percentage of canopy opening, and 8) altitude. The same forest structure components were also recorded in 50 x $50 \mathrm{~m}$ plots established where tamarins were not seen (control plots). These plots were located at a minimum of $500 \mathrm{~m}$ from those where tamarins had been recorded.
Tamarins usually depend on vertical support or tree trunks to forage. We hypothesized that, due to the greater availability of spots to perch and forage, forest areas with a greater abundance of trees could be more attractive to these primates than areas with fewer trees.

Therefore, in the $50 \times 50 \mathrm{~m}$ plots, all trees with DBH equal to or greater than $10 \mathrm{~cm}$, and all lianas with DBH exceeding 5 $\mathrm{cm}$, were counted. We also recorded all trees and lianas that were fruiting. The total number of forest trees $(\mathrm{DBH}>10 \mathrm{~cm})$ in each $50 \times 50 \mathrm{~m}$ plot was used as an index of tree abundance in the analyses.

All forest logs (diameter $>20 \mathrm{~cm}$ ) and forest snags were counted within each plot, and their total numbers were used as an index of abundance in the analyses. Sites with more logs and snags are probably attractive to tamarins, because they may offer food that is more readily available and easier to catch, such as decomposing insect larvae inside the dead trunks.

Primates of the family Callitrichinae have been observed descending to the forest ground to search for food (Pinder, 1986; Tavares, 1999). S. bicolor was observed go down to the forest floor during periods of food scarcity which occurs during the dry season (Marcelo Vidal, Pers. Obs, 2003). We believe that areas with more leaf litter accumulated in the forest probably have more arthropod abundance and could be visited more by the tamarins than areas with shallow leaf litter. The leaf litter depth was recorded by inserting a knife blade on the forest floor and counting the number of impaled dead leaves. We recorded the leaf litter layers on the four corners and at the center of twenty-one $1 \mathrm{~m}^{2}$ subplots located $10 \mathrm{~m}$ equidistant from each other, with 20 sub-lots distributed along the sides, and one at the center of each $50 \times 50 \mathrm{~m}$ plot. The mean value of 21 plots within the $50 \times 50 \mathrm{~m}$ plot was used in the analyses.

Areas with more canopy opening in the forest allow more direct light to enter, and may contribute to increase chances of detection of tamarins by soaring hawks and eagles predators which often attacks primates and other vertebrates visiting the forest canopy. Therefore, we hypothesized that more illuminated sites would not be visited very often by tamarins.

The forest canopy opening was recorded using a Spherical Crown Densiometer (Concave-Mode C-Robert E. Lemonn, Forest Densiometer, 5733 SE Cornell Dr. - Bartlesville, OK, USA). We did four readings (to the north, south, east and west) in each of the four subplots at the corners, and in a subplot at the center of the $50 \times 50 \mathrm{~m}$ plot. According to the instrument recommendations, each reading was multiplied by 1.04 , and the mean value of the 5 subplots was the one used in analyses.

Forest valleys where aquatic environments are abundant are more humid and may have a greater abundance of insects and other arthropods than much drier sites farther away in the uplands, and they could be more attractive to primates, simply 
because of food sources that are more readily available and easier to catch. The data on altitude was collected from a map with topographic cotes recorded by a team of topographers (using theodolite and clinometers) during the time the trails were openned.

\section{STATISTICAL ANALYSIS}

For the data recorded in the $50 \times 50 \mathrm{~m}$ plots, three Pearson correlation analysis were done to verify whether correlations among the independent variables (the forest structure components) were significant. The independent variables that were significantly correlated were used in separate multiple regression models. This procedure was done for the same group of independent variables, however, the amount of plots and consequently the values of the variables were different depending on the models in which they were used. For example the sample size was $\mathrm{n}=82$ for the analysis of occurrence of tamarins (in which logistic regression was used; 41 plots with tamarins and 41 plots without tamarins), was $n=41$ to analyze the effects of forest structure on tamarin group size, and $n=16$ to analyze the effects of forest structure on density of groups of tamarins (see below). Because Pearson regression analysis run the correlations of the variables using pair of independent variables and do not correlates all of them together, we also run multiple correlations using each independent variable at the time as dependent variable against all the other independent ones, and verified the values of the tolerance to help us decide which variables would go together in the same models of regression.

We used multiple logistic regression analyses, available in the Systat Program (Wilkinson 1998), to investigate the effects of forest structure components on occurrence of the tamarin groups, because the dependent variable is categorical (tamarin group present $=1$, and tamarin group absent $=0$ ).

The effects of forest structure components on variation in the group size of tamarin were evaluated using multiple linear regression models in which the dependent variable was the group size. The effects of forest structure components on variation in density of groups of tamarin (dependent variable) were also evaluated using multiple linear regression models. The statistical program Systat version 8.0 (Wilkinson, 1998) was used to run the analysis.

In order to have more independent observations for the latter analyses, we sub-divided the entire trail grid in blocks of 4 $\mathrm{km}^{2}$ and counted the groups of tamarins. We had, therefore sixteen $4 \mathrm{~km}^{2}$ blocks and the tamarins groups density recorded within them varied from (0) zero to 5 . Because of the small sample size (16 blocks), we used three groups of independent variables (forest structure components), as following: the first model using abundance of snags, abundance of logs and abundance of trees and lianas in fruiting; the second model using abundance of trees, abundance of lianas, and altitude; and the third model using canopy opening and leaf litter depth.

\section{RESULTS}

We recorded 41 groups of the tamarin Saguinus bicolor along the trails system of the Ducke Reserve (Figure 1). Twenty groups were recorded in areas of plateau (between 110 and $140 \mathrm{~m}$ of altitude), twelve groups were located in areas of slopes or sloping terrain (altitude ranging from 70 to $100 \mathrm{~m}$ ), and nine were recorded in the lowlands or "baixios" (between 40 and $60 \mathrm{~m}$ of altitude). The group size ranged from 2 to 11 individuals, with a mean of 4.8 individuals $(\mathrm{n}=41)$.

\section{OCCURRENCE OF Saguinus bicolor GROUPS IN RELATION TO VARIATION IN THE COMPONENTS OF FOREST STRUCTURE.}

Correlations between the forest structure components for the analysis with the occurrence of S. bicolor - For the forest components recorded in areas with (41 plots) and without (41 plots) the occurrence of $S$. bicolor, forest tree abundance was significantly correlated with forest $\log$ abundance $(r=0.351, \mathrm{p}<0.034)$, and this was correlated with canopy opening $(r=0.495, \mathrm{p}<0.0001)$. The other forest structure components showed no significant correlations among them.

The occurence of $S$. bicolor groups had a inverse and significant relationship with abundance of logs (Multiple logistic regression, MacFadden's Rho-squared (MRS) $=0.151 ; \mathrm{N}=82$; $\mathrm{T}=-3.601 ; \mathrm{P}=0.0001$ ), and with forest canopy opening $(\mathrm{MRS}=0.226 ; \mathrm{N}=82 ; \mathrm{T}=-2.476 ; \mathrm{P}=0.013)$, indicating that S. bicolor more often uses areas in the forest with lower abundance of forest logs and more shaded understory or smaller canopy opening. There was also a positive relationship between the occurence of groups of S. bicolor and the abundance of snags $(\mathrm{MRS}=0.226 ; \mathrm{N}=82 ; \mathrm{T}=2.214 ; \mathrm{P}=0.027)$ suggesting that S. bicolor uses more often areas with higher abundance of snags more frequently.

There was no significant relationship between the other forest structure components and the frequency of occurence of the $S$. bicolor (abundance of trees: $\mathrm{MRS}=0.226, \mathrm{~N}=82, \mathrm{~T}=0.410$, $\mathrm{P}=0.682$; abundance of lianas: $\mathrm{MRS}=0.226, \mathrm{~N}=82, \mathrm{~T}=$ $0.885, \mathrm{P}=0.376$; abundance of trees and lianas in fruiting: $\mathrm{MRS}=0.226, \mathrm{~N}=82, \mathrm{~T}=1.739, \mathrm{P}=0.082$; leaf litter depth: $\mathrm{MRS}=0.226, \mathrm{~N}=82, \mathrm{~T}=0.202, \mathrm{P}=0.840$; altitude: $\mathrm{MRS}=$ $0.226, \mathrm{~N}=82, \mathrm{~T}=-1.530, \mathrm{P}=0.126$ ).

\section{VARIATION IN THE GROUP SIZE OF Saguinus bicolor IN RELATION TO THE FOREST STRUCTURE.}

Correlations between the forest structure components for the analysis with the variation in group size of S. bicolor - For the forest components recorded only in areas (41 plots) in which the groups of S. bicolor occurred, the forest structure components showed no significant correlations among them. Therefore, we use all independent variables (forest structure components) together in the same multiple linear regression model.

There was no significant relationship among the forest structure components and the group size of S. bicolor (abundance 
of trees, Multiple linear regression analysis, $\mathrm{R}^{2}=0.208, \mathrm{~N}=41$, $\mathrm{T}=-0.149, \mathrm{P}=0.883$; abundance of lianas: $\mathrm{R}^{2}=0.208, \mathrm{~N}=$ $41, \mathrm{~T}=-1.376, \mathrm{P}=0.178$; abundance of trees and lianas in fruiting: $\mathrm{R}^{2}=0.208, \mathrm{~N}=41, \mathrm{~T}=0.055, \mathrm{P}=0.956$, abundance of logs: $\mathrm{R}^{2}=0.208, \mathrm{~N}=41, \mathrm{~T}=1.340, \mathrm{P}=0.190$; abundance of snags: $\mathrm{R}^{2}=0.208, \mathrm{~N}=41, \mathrm{~T}=-0.319, \mathrm{P}=0.752$; leaf litter depth: $\mathrm{R}^{2}=0.208, \mathrm{~N}=41, \mathrm{~T}=1.315, \mathrm{P}=0.198$; canopy opening: $\mathrm{R}^{2}=0.208, \mathrm{~N}=41, \mathrm{~T}=-0.621, \mathrm{P}=0.539$ and altitude: $\mathrm{R}^{2}=0.208, \mathrm{~N}=41, \mathrm{~T}=0.909, \mathrm{P}=0.370$ ).

\section{VARIATION IN THE DENSITY OF GROUPS OF Saguinus bicolor IN RELATION TO THE FOREST STRUCTURE.}

Correlations between the forest structure components for the analysis with the density of groups of S. bicolor - For the forest components recorded in the blocks of $4 \mathrm{~km}$ in which the density of groups of $S$. bicolor was recorded, the forest log abundance and snags abundance were significantly correlated with leaf litter depth $(\mathrm{r}=0.472, \mathrm{p}<0.05) ; \mathrm{r}=-0.339, \mathrm{p}<0.05$, respectively). Log abundance was also correlated with lianas abundance $(\mathrm{r}=$ $0.343, \mathrm{p}<0.05)$, and snags abundance was correlated with abundance of trees and lianas fruiting $(r=0.345, p<0.05)$. The other forest structure components showed no significant correlations among them.

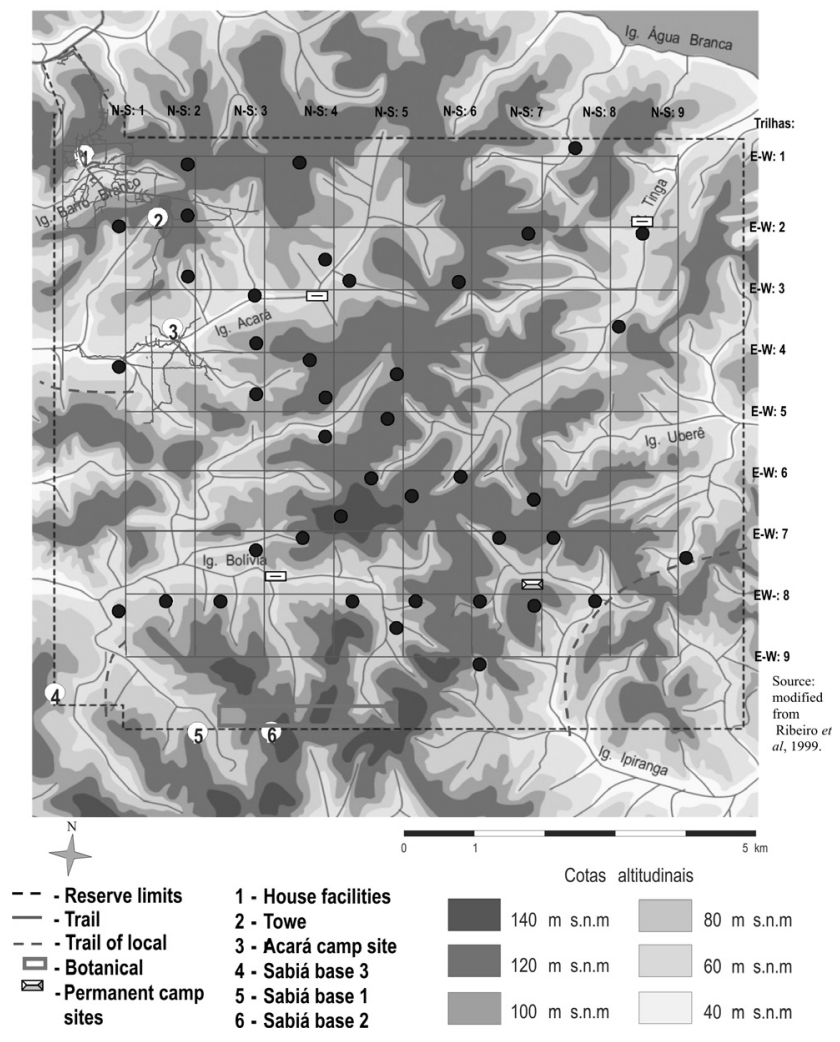

Figure1 - Spatial distribution map of the Bare-face Tamarin (S. bicolor) groups within the area of Ducke Reserve. Each spot represents a tamarin group.
The density of groups of $S$. bicolor had an inverse and significant relationship with forest canopy opening (Multiple linear regression analysis, $\mathrm{R}^{2}=0.339 ; \mathrm{N}=16 ; \mathrm{T}=-2.370 ; \mathrm{P}=$ 0.034; Figure 2), indicating that areas in the forest with smaller canopy opening were visited by a higher number of groups of $S$. bicolor.

There was no significant relationship between the other forest structure components and the density of groups of S. bicolor in the Ducke Reserve forest (abundance of trees: $\mathrm{R}^{2}=0.052, \mathrm{~N}=$ $16, \mathrm{~T}=-0.352, \mathrm{P}=0.731$; abundance of lianas: $\mathrm{R}^{2}=0.052, \mathrm{~N}$ $=16, \mathrm{~T}=-0.457, \mathrm{P}=0.656$; abundance of trees and lianas in fruiting: $\mathrm{R}^{2}=0.184, \mathrm{~N}=16, \mathrm{~T}=-0.034, \mathrm{P}=0.974$; abundance of logs: $\mathrm{R}^{2}=0.184, \mathrm{~N}=16, \mathrm{~T}=-0.276, \mathrm{P}=0.787$; abundance of snags: $\mathrm{R}^{2}=0.184, \mathrm{~N}=16, \mathrm{~T}=1.547, \mathrm{P}=0.148$; leaf litter depth: $\mathrm{R}^{2}=0.339, \mathrm{~N}=16, \mathrm{~T}=-0.529, \mathrm{P}=0.606$ and altitude: $\left.\mathrm{R}^{2}=0.052, \mathrm{~N}=16, \mathrm{~T}=0.548, \mathrm{P}=0.594\right)$.
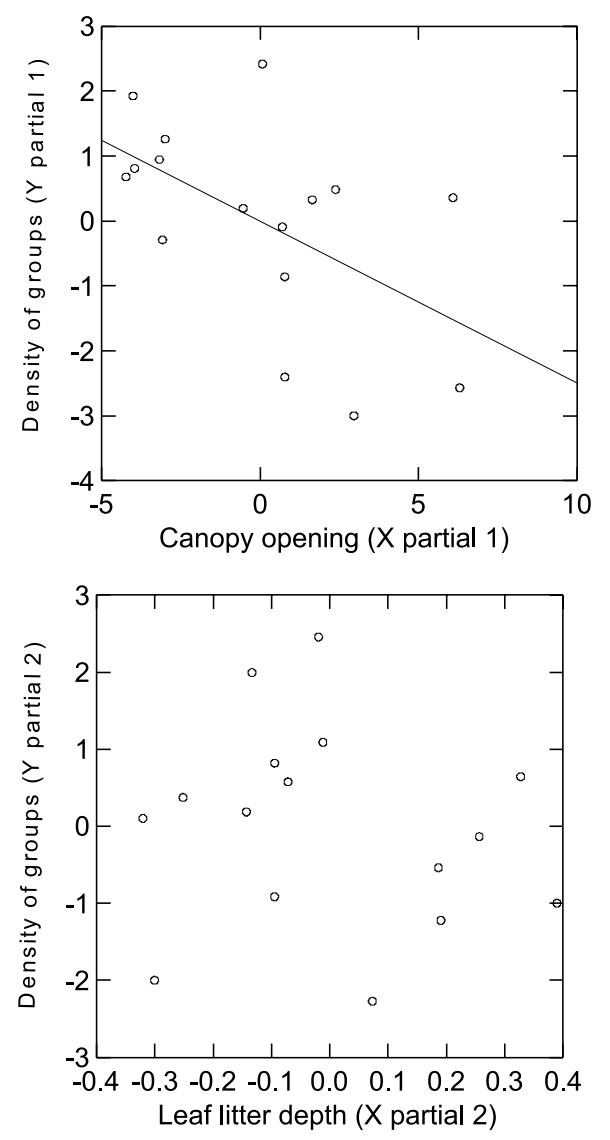

Figure 2 - Partial regressions of density of Bare-face Tamarin (S. bicolor) groups in relation to canopy opening and leaf litter depth. Some numbers in the axis are negative because the partial regression represents the deviation of the expected results if all the other independent variables are kept constant in their observed means. 


\section{DISCUSSION}

The results of this study showed that $S$.bicolor is widely distributed in the reserve Ducke including areas of plateaus, slopes and lowlands. Ample spatial distribution has also been documented for other species of tamarins in Amazonia (Terborgh 1983, Peres 1994). Although we recorded 41 groups there may be more. This is because we conducted the surveys mostly on the vicinities and along the trails in the reserve trail systems, and we did not walk into the areas off trail or in the interior of the sixty four 100 ha continuous forest blocks. Since we had a relatively large number of tamarin groups, we believe that our results can be generalized for the area. A recent survey in which a group of $S$. bicolor was radio-tracked in the reserve Ducke is showed that this species had a territory size of about 100 hectares (Marcelo Gordo, Pers. Com.). Therefore, we believe that the number of groups occurring in the reserve is about the one we found.

Most of the Tamarin groups (about 50\%) occurred in the plateau areas, even though there was no significant effects of altitude in the occurence, group size and density of groups. There might be some forest resources (food, nesting spots, refuges to escape from predators) attractive to this tamarin in the uplands, but this needs further investigation.

The variation in group size was also in concordance with some other tamarins species studied in the region (Peres 1994) and it may reflects the demographic dynamics of the species. One important finding in our study is that juveniles were recorded in many groups which indicates that $S$. bicolor is breeding in the reserve. This species also occurs in areas around the reserve including in many forest patches in Manaus. Because forest fragmentation and habitat deforestation are under strong development in Manaus area we strongly recommend the integral preservation of reserve Ducke in order to maintain viable and breeding populations of S. bicolor in central Amazon.

Intra-specific variations in habitat use by primates can be associated with spatial and temporal variations in resources such as food, water availability, or local forest structure that provides a good environment for locomotion, foraging and protections against predators (Oates, 1987; Rylands, 1986).

Concentration of lianas and bromelias, and barks of snags, were substrates used more often for foraging by Golden Lion Tamarin (Leontopithecus rosalia), where they could even find small vertebrates such as lizards and frogs (Pinder, 1986). Tamarins have also been documented searching for food in leaves, twigs, and holes in snags, and this has been considered a strategic behaviour for searching for immature insects (Ferrari, 1988).

Thorstrom et al. (2000) observed that owl species that nest inside empty snags are more strongly affected by predation on their nests. The authors suggests that nest predators, and $S$. bicolor is a nest predator, tend to visit snags more often when they are searching for animal protein. According to Glinski et al. (1983), nests in snags are more easily located by predators who usually visit spots with abundant snags to search for prey.

Primates of the family Callitrichinae have been observed descending to the forest ground to search for food. Silvery marmoset (C. argentata) was observed by Tavares (1999) searching for prey in cavities on the forest floor, in ant nests and termite nests at the base of forest logs. He noted that these primates were more apprehensive, and when disturbed, they scurried to climb the nearest tree. Golden lion Tamarin ( $L$. rosalia), was also observed going down to the forest floor to capture insects near forest logs and under the leaf litter, but stopping for a few minutes at $1.5 \mathrm{~m}$ height to look around, and after catching the prey, returning quickly to the forest canopy (Pinder, 1986). The tendency of S. bicolor in using the areas bearing lower abundance of forest logs, as our results indicates, confirms the findings of earlier studies on other small primates. As many other neotropical primates, S. bicolor go down to the forest floor during periods of food scarcity which occurs during the dry season. Although they search for near the logs (where insect larvae is more abundant) they don't spend much time foraging on the forest floor (Marcelo Vidal, Pers. Obs, 2003).

The visual exploration of the environment from elevated spots helps the animal to locate its prey and prevent attacks from terrestrial predators (Tavares, 1999). However, areas with complex forest structure (such as those with a greater abundance of logs, snags and leaf litter), although attractive, are also visited by terrestrial predators, such as snakes and cats, that use them as temporary spots for resting and waiting for prey.

It has been suggested that Callitrichinae, in general, prefers secondary forest with dense understory and mature forest edges (Goldizen, 1987; Terborgh, 1983). This is because tamarins are insectivores-frugivores, and insects and fruits are more readily available in secondary vegetation than in mature forests (Mittermeier \& van Roosmalen, 1981; Yoneda, 1984).

Peres (1992) found $S$. fuscicollis exploring closed and complex micro-habitats and lower canopy in tropical forests. Saguinus bicolor also explore spots with small trees and treelets for feeding (Egler, 1986). Their low body weight (between 400 and 560 $\mathrm{g}$ ), even as adults, allows easy access to fruits, including those located at the tips of the smallest branches. However, prolonged exposure in open areas of the forest canopy can be dangerous, due to possible attacks of soaring avian raptors coming from above such as hawks and eagles. Lindsay (1979) observed that individuals of Saguinus oedipus never expose themselves for long periods when foraging on the exposed branches. The presence of soaring birds has lead groups of $S$. bicolor to descend quickly to the lower parts of the trunks of the trees where they were foraging (Egler, 1986). This behavior, followed by intense warning calls, was also recorded for Saguinus nigricollis after 
falcons (Micrastur ruficollis) and eagles (Harpia harpyja) where seen soaring overhead (Izawa, 1978).

The size of the canopy opening seems to be related to the sites chosen by the tamarins for resting and safety against attacks by predators, and has been one of the main determining factors affecting selection of areas for resting. Among the different vegetation types, mature forests with tall trees and more closed canopy were the only habitat used for resting by spider monkeys (Anderson, 1984). A lower frequency of use of areas with larger canopy openings could be explained as a strategy of S. bicolor to protect themselves against attacks of predators coming from above, such as hawks and eagles, since in those spots, the groups of S. bicolor could be more easily located.

Ecological studies produce important information for the development of strategies to conserve threatened species. The spatial distribution of small primates can be affected by many things including their territorial behavior, defense against predator attacks, and within group social interactions (Terborgh 1983). Although there is some recognized behavioral flexibility in the family Callitrichinae, the results of this study suggests that the distribution and abundance of by S. bicolor may be also in response to the environmental heterogeneity created by changes in forest structure. This indicates that $S$. bicolor does not use its home range area in a random manner, and is influenced by some forest structure components (such as forest logs, snags, and canopy opening) whose effects on this tamarin have never been investigated before in such a large spatial scale in other areas where this species occurs. The relationship between the spatial distribution of tamarins and the heterogeneity create by the forest structure in a given area is important to understand microhabitat use and preferences and habitat use and selection by this primate species, and this should be considered in any attempt to conserve this primate species.

\section{ACKNOWLEDGMENTS}

We wanted to thank José Geronimo Ferreira Leite (Gera), and Lucas Mergulhão for their competent field assistance. We thank Marcelo Gordo who shared with us is knowledge on Bare-face Tamarin. Conselho Nacional de Desenvolvimento Científico e Tecnológico (CNPq) and Coordenação de Aperfeiçoamento de Pessoal de Nível Superior (CAPES) gave the scholarship to Marcelo Derzi Vidal. We also thank the World Wildlife Foundation (WWF), Ford Foundation, and the Programa Natureza e Sociedade of Instituto Internacional de Educação no Brasil (IEB) for the financial support. This study also received logistic support by Instituto Nacional de Pesquisas da Amazônia (INPA), CNPq-PNOPg, CNPq-PELD.

\section{LITERATURE CITED}

Anderson, J.R. 1984. Ethology and ecology of sleeping in monkeys and apes. Advanc. Study Behav. 14:165-229.
Egler, S.G.1986. Estudos bionômicos de Saguinus bicolor bicolor (Spix, 1823) (Callitrichidae, Primates), em mata tropical alterada, Manaus, $A M$. Dissertação de Mestrado. Universidade Estadual de Campinas, Campinas.

Ferrari, S.F.1988. The behaviour and ecology of the Buffy-headed marmoset, Callithrix flaviceps (Thomas, 1903). Ph.D. Thesis, University College, London.

Ferrari,M.A.1993. Conservação do cuxiú-preto, Chiropotes satanas satanas (Cebidae, Primates), e de outros mamíferos na Amazônia Oriental. Dissertação de Mestrado. Universidade Federal do Pará.

Garber, P.A. 1991. Seasonal variation in diet and ranging patterns in two species of tamarin monkeys. American Journal of Physical Anthropology, Suppl. 12:75.

Garber, P.A. 1993. Feeding ecology and behaviour of the genus Saguinus. In: Rylands, A.B. (Ed.). Marmosets and Tamarins: Systematics, Behaviour, and Ecology, Oxford University Press, New York .p. 273-295.

Goldizen, A.W. 1987. Tamarins and Marmosets: Communal Care of Offspring. Primate Societies. The University of Chicago Press. Chicago, 578 pp.

Izawa, K. 1978. A field study of the ecology and behavior of the black-mantle tamarin (Saguinus nigricollis). Primates, 19(2) : 241-274.

Lindsay, N.B.D. 1979. A report on field study of Geoffroy's tamarin Saguinus oedipus geoffroyi. Dodo J. Jersey Wild Press Trust 16:2751.

McNab, B.K. 1983. Bioenergetics and the determination of home range size. American Naturalist, 97. 894:133-140.

Mittermeier, R.A.; Van Roosmalen, M.G.M. 1981. Preliminary observations on habitat utilization and diet in eight Surinam monkeys. Folia Primatologica, 44:82-95.

Oates, J.F. 1987. Food distribution and foraging behavior, In: Smuts, B.B.; Cheney, D.L.; Seyfarth, R.M.; Wrangham, R.W.; Struhsaker, T.T. (Eds.). Primate Societies. Chicago University Press. Chicago. p. 197-209

Padua, C.V. 1993. The ecology, behavior and conservation of the black lion tamarins (Leontopithecus chrysopygus, Mikan, 1823). PhD. Thesis. University of Florida. Florida. 163pp.

Peres, C.A.S. 1991. Ecology of mixed-species groups of tamarins in Amazonian terra firme forests. Primate Eye, 44 :5-6.

Peres, C.A.S. 1992. Diet and feeding ecology of saddle-back (Saguinus fuscicollis) and moustached (Saguinus mystax) tamarins in an Amazonian terra firme forest. Journal of Zoology, 230 :567-592.

Peres, C.A.S. 1993. Structure and spatial organization of an Amazonian terra firme forest primate community. Journal of Tropical Ecology, 9: 259-276.

Peres, C.A.S. 1997. Primate community structure at twenty western Amazonian flooded and unflooded forests. Journal of Tropical Ecology, 13: 381-405.

Pinder, L. 1986. Translocação como técnica de conservação em Leontopithecus rosalia. Projeto Mico Leão Dourado. 66pp.

Ribeiro, J.E.L.Da S.; Hopkins, M.J.G.; Vicentini A.; Sothers, C. A.; Costa M.A.; Brito, J.M.; Souza, M.A.D.; Martins L.H.P.; 


\section{ACTA
AMAZONICA}

EFFECTS OF FOREST STRUCTURE COMPONENTS ON THE OCCURRENCE, GROUP SIZE AND DENSITY OF GROUPS

OF BARE-FACE TAMARIN (Saguinus bicolor - PRIMATES: CALLITRICHINAE) IN CENTRAL AMAZONIA

Lohmann, L.G.; Assunção, P.A.; Pereira, E.C.; Silva, C.F.da; Mesquita, M.R.; Procópio, L.C. 1999. Flora da Reserva Ducke - Guia de identificação das plantas vasculares de uma floresta de terra-firme na Amazônia Central. Instituto Nacional de Pesquisas da Amazônia. Manaus, Amazonas. 816 pp.

Rylands, A.B. 1986. Ranging behaviour and habitat preference of a wild marmoset group, Callithrix humeralifer (Callitrichidae, Primates). Journal of Zoology, 210 :489-514.

Rylands, A.B.; Faria, D.S. 1993. Habitats, feeding ecology, and home range size in the genus Callithrix, In: Rylands, A.B. (Ed.), Marmosets and Tamarins: Systematics, Behaviour, and Ecology. Oxford University Press, New York. pp. 262-272.

Rylands, A.B.; Schneider, H.; Languth, A.; Mittermeier, R.A.; Groves, C.P.; Rodriguez-Lun, E. 2000. An Assessment of the Diversity of New World Primates. Neotropical Primates. 8(2) : 61-93.

Stevenson, M.F.; Rylands, A.B. 1988. The marmosets, genus Callithrix, In: Mittermeier, R.A.; Rylands, A.B.; Coimbra-Filho, A.F.; Fonseca, G.A.B. (Eds.), Ecology and behavior of neotropical primates, Vol. 2., World Wildlife Fund, Washington. p.131222,

Spironello, W. 2001. The Brown Capuchin Monkey (Cebus apella): Ecology and Home Range Requirements in Central Amazonia, In: Laurence, W.; Bierregaad, R. (Eds.), Lessons from Amazonia:
The ecology and conservation of a fragmented forest. Sheridan Books. Michigan, USA. p.271-283.

Subirá, R. 1998. Avaliação das populações selvagens do sauím-de-coleira - Saguinus bicolor bicolor (Spix, 1823). Dissertação de Mestrado. Departamento de Ecologia da Universidade de Brasília. Brasilia.

Tavares, L.I. 1999. Estratégias de forrageio de um grupo silvestre de sagui-branco (Callithrix argentata Linnaeus, 1771) na estação cientifica Ferreira Penna-MPGE/CNPq. Melgaço, Pará-Brasil. Master's Thesis. Departamento de Psicologia Experimental da Universidade Federal do Pará. Belém. 100pp.

Terborgh, J. 1983. Five New World Primates: a study in comparative ecology. Princeton University Press, Princeton, N.J. p. 260.

Throstrom, R.; Ramos, J.D.; Morales, C.M. 2000. Breeding biology of barred Forest-falcons (Micrastur rufficollis) in northeastern Guatemala. $A u k, 117(3): 781-786$.

Wilkinson, L. 1998. Systat: The system for statistics. SPSS Inc. Evanston, IL.

Yoneda, M. 1984. Ecological study of the saddle-backed tamarin (Saguinus fuscicollis) in northern Bolivia. Primates, 25:1-12.

Recebido em 01/07/05

Aceito em 23/01/06 
Appendix 1 - Data on bare-face tamarin (S. bicolor) occurrence and forest structure components in Central Amazon forest.

\begin{tabular}{|c|c|c|c|c|c|c|c|c|c|c|c|}
\hline Trail & Position & Occurrence & Group size & Trees & Logs & Snags & Leaf litter & $\begin{array}{l}\text { Canopy } \\
\text { opening }\end{array}$ & Altitude & Lianas & $\begin{array}{l}\text { Trees and lianas } \\
\text { Fruiting }\end{array}$ \\
\hline $\mathrm{L} 1$ & 2430 & 1 & 4 & 165 & 9 & 15 & 2 & 11.44 & 120 & 25 & 3 \\
\hline L1 & 1800 & 0 & 0 & 99 & 17 & 9 & 2.19 & 31.2 & 120 & 26 & 3 \\
\hline L1 & 5600 & 0 & 0 & 188 & 6 & 2 & 2.14 & 20.8 & 90 & 21 & 2 \\
\hline L1 & 6500 & 1 & 3 & 187 & 10 & 4 & 2.47 & 20.8 & 90 & 29 & 2 \\
\hline L2 & 5900 & 1 & 4 & 121 & 14 & 2 & 2.42 & 19.76 & 120 & 22 & 1 \\
\hline L2 & 950 & 1 & 10 & 160 & 12 & 4 & 2.66 & 9.36 & 120 & 17 & 0 \\
\hline L2 & 6600 & 0 & 0 & 151 & 9 & 4 & 2.09 & 16.64 & 100 & 17 & 0 \\
\hline L2 & 3400 & 0 & 0 & 97 & 23 & 2 & 1.85 & 18.72 & 80 & 17 & 1 \\
\hline L2 & 5100 & 0 & 0 & 121 & 17 & 3 & 2.52 & 19.76 & 120 & 27 & 2 \\
\hline L2 & 7500 & 1 & 5 & 162 & 15 & 2 & 2.19 & 17.68 & 60 & 21 & 2 \\
\hline L2 & 1500 & 0 & 0 & 112 & 16 & 2 & 2 & 18.72 & 80 & 38 & 0 \\
\hline L3 & 1920 & 1 & 2 & 133 & 6 & 6 & 1 & 14.56 & 40 & 11 & 1 \\
\hline L3 & 4850 & 1 & 3 & 168 & 3 & 7 & 2 & 10.4 & 120 & 28 & 1 \\
\hline L3 & 3100 & 1 & 5 & 138 & 8 & 13 & 2.38 & 15.6 & 80 & 49 & 1 \\
\hline L3 & 2200 & 1 & 6 & 166 & 4 & 7 & 2.52 & 12.48 & 60 & 12 & 1 \\
\hline L3 & 5600 & 0 & 0 & 192 & 10 & 3 & 2.19 & 17.68 & 90 & 28 & 1 \\
\hline L4 & 2650 & 1 & 4 & 142 & 6 & 7 & 2.33 & 13.52 & 90 & 13 & 1 \\
\hline L4 & 4900 & 0 & 0 & 159 & 10 & 3 & 2.14 & 18.72 & 90 & 44 & 1 \\
\hline L5 & 4500 & 0 & 0 & 113 & 12 & 6 & 2.38 & 14.56 & 120 & 32 & 1 \\
\hline L5 & 3700 & 1 & 3 & 134 & 4 & 4 & 2.66 & 9.36 & 120 & 37 & 1 \\
\hline L5 & 300 & 0 & 0 & 162 & 25 & 2 & 2.33 & 30.16 & 90 & 12 & 0 \\
\hline L6 & 4800 & 1 & 2 & 152 & 13 & 8 & 1.75 & 16.64 & 90 & 68 & 1 \\
\hline L6 & 2200 & 0 & 0 & 162 & 11 & 2 & 2.19 & 18.72 & 90 & 20 & 1 \\
\hline L6 & 5300 & 0 & 0 & 209 & 10 & 3 & 1.85 & 18.72 & 90 & 36 & 2 \\
\hline L6 & 3500 & 1 & 7 & 112 & 17 & 10 & 2 & 20.8 & 120 & 26 & 0 \\
\hline L7 & 5400 & 1 & 6 & 151 & 14 & 11 & 2.42 & 14.56 & 120 & 30 & 2 \\
\hline L7 & 3500 & 0 & 0 & 88 & 23 & 3 & 1.95 & 19.76 & 120 & 15 & 2 \\
\hline L7 & 7000 & 0 & 0 & 210 & 10 & 11 & 1.42 & 27.04 & 120 & 14 & 3 \\
\hline L7 & 2970 & 1 & 11 & 161 & 5 & 6 & 2.04 & 9.36 & 140 & 23 & 1 \\
\hline L7 & 4500 & 0 & 0 & 148 & 7 & 6 & 2.42 & 18.72 & 120 & 24 & 1 \\
\hline L7 & 2500 & 1 & 8 & 94 & 21 & 14 & 1.95 & 19.76 & 100 & 20 & 1 \\
\hline$\underline{\mathrm{L}}$ & 1250 & 1 & 5 & 125 & 6 & 4 & 2 & 10.4 & 60 & 29 & 2 \\
\hline L8 & 3300 & 1 & 7 & 117 & 15 & 0 & 2.23 & 19.76 & 80 & 21 & 4 \\
\hline L8 & 160 & 1 & 7 & 134 & 6 & 5 & 2.42 & 12.48 & 60 & 23 & 1 \\
\hline L8 & 700 & 1 & 6 & 105 & 12 & 7 & 2.19 & 19.76 & 60 & 64 & 2 \\
\hline L8 & 6500 & 1 & 4 & 185 & 14 & 11 & 2.04 & 12.48 & 80 & 42 & 4 \\
\hline L8 & 5600 & 1 & 7 & 211 & 11 & 5 & 1.61 & 17.68 & 120 & 31 & 0 \\
\hline L8 & 4600 & 0 & 0 & 180 & 16 & 7 & 1.23 & 17.68 & 120 & 26 & 0 \\
\hline L8 & 5100 & 1 & 5 & 221 & 14 & 9 & 1.52 & 23.92 & 110 & 38 & 4 \\
\hline L8 & 2700 & 0 & 0 & 87 & 22 & 4 & 2.09 & 19.76 & 80 & 33 & 1 \\
\hline L9 & 4500 & 0 & 0 & 131 & 12 & 9 & 2.19 & 12.48 & 130 & 34 & 0 \\
\hline L9 & 3500 & 0 & 0 & 101 & 22 & 5 & 2.42 & 21.84 & 110 & 27 & 0 \\
\hline L9 & 6500 & 0 & 0 & 188 & 9 & 8 & 1.8 & 12.48 & 100 & 30 & 1 \\
\hline L9 & 400 & 0 & 0 & 112 & 18 & 4 & 2.19 & 20.8 & 100 & 18 & 1 \\
\hline N1 & 3200 & 1 & 9 & 141 & 4 & 4 & 2 & 14.56 & 40 & 18 & 1 \\
\hline N1 & 1000 & 1 & 3 & 149 & 7 & 5 & 1 & 13.52 & 80 & 23 & 2 \\
\hline N1 & 7300 & 1 & 3 & 158 & 4 & 6 & 1.04 & 11.44 & 80 & 20 & 2 \\
\hline
\end{tabular}




\begin{tabular}{|c|c|c|c|c|c|c|c|c|c|c|c|}
\hline Trail & Position & Occurrence & Group size & Trees & Logs & Snags & Leaf litter & $\begin{array}{l}\text { Canopy } \\
\text { opening }\end{array}$ & Altitude & Lianas & $\begin{array}{l}\text { Trees and lianas } \\
\text { Fruiting }\end{array}$ \\
\hline N1 & 6500 & 0 & 0 & 120 & 19 & 5 & 2.14 & 19.76 & 90 & 9 & 0 \\
\hline N1 & 2500 & 0 & 0 & 183 & 11 & 2 & 2.23 & 40.56 & 60 & 28 & 2 \\
\hline N1 & 4000 & 0 & 0 & 180 & 8 & 2 & 2.04 & 23.92 & 90 & 25 & 1 \\
\hline N1 & 1500 & 0 & 0 & 128 & 17 & 2 & 2 & 18.72 & 80 & 12 & 0 \\
\hline N1 & 500 & 0 & 0 & 121 & 15 & 4 & 2.14 & 17.68 & 90 & 12 & 1 \\
\hline N2 & 6600 & 0 & 0 & 118 & 13 & 0 & 2.19 & 20.8 & 60 & 9 & 0 \\
\hline N2 & 160 & 1 & 4 & 148 & 5 & 13 & 2.09 & 13.52 & 120 & 8 & 0 \\
\hline N2 & 1900 & 1 & 5 & 98 & 11 & 3 & 2 & 20.8 & 80 & 19 & 0 \\
\hline N2 & 2500 & 0 & 0 & 117 & 19 & 3 & 1.95 & 18.72 & 60 & 26 & 0 \\
\hline N2 & 7600 & 0 & 0 & 131 & 14 & 1 & 2.04 & 19.76 & 120 & 21 & 1 \\
\hline N2 & 3300 & 0 & 0 & 116 & 13 & 1 & 1.71 & 18.72 & 90 & 8 & 0 \\
\hline N3 & 3700 & 1 & 3 & 158 & 6 & 5 & 1.33 & 10.4 & 80 & 28 & 1 \\
\hline N3 & 6200 & 1 & 5 & 139 & 4 & 6 & 1.76 & 12.48 & 80 & 18 & 2 \\
\hline N3 & 2900 & 1 & 5 & 153 & 10 & 5 & 2.33 & 10.4 & 100 & 25 & 0 \\
\hline N3 & 5400 & 0 & 0 & 117 & 18 & 1 & 2 & 19.76 & 90 & 11 & 0 \\
\hline N3 & 1600 & 0 & 0 & 119 & 14 & 7 & 2 & 24.96 & 90 & 19 & 3 \\
\hline N3 & 6700 & 0 & 0 & 116 & 13 & 5 & 2.19 & 19.76 & 80 & 22 & 0 \\
\hline N4 & 3800 & 1 & 6 & 147 & 4 & 5 & 2.28 & 13.52 & 100 & 20 & 4 \\
\hline N4 & 4600 & 1 & 8 & 118 & 17 & 2 & 2.66 & 18.72 & 80 & 18 & 3 \\
\hline N4 & 1500 & 1 & 3 & 135 & 9 & 11 & 2.19 & 14.56 & 80 & 12 & 1 \\
\hline N5 & 2920 & 1 & 5 & 162 & 4 & 9 & 2.14 & 14.56 & 120 & 21 & 2 \\
\hline N5 & 1500 & 0 & 0 & 136 & 28 & 12 & 1.33 & 45.76 & 120 & 32 & 0 \\
\hline N5 & 3400 & 1 & 4 & 112 & 9 & 2 & 1.38 & 43.68 & 120 & 20 & 0 \\
\hline N5 & 2300 & 0 & 0 & 98 & 16 & 1 & 2 & 17.68 & 120 & 63 & 1 \\
\hline N5 & 5500 & 1 & 6 & 197 & 18 & 8 & 2.04 & 20.8 & 120 & 18 & 0 \\
\hline N7 & 5500 & 1 & 7 & 203 & 15 & 10 & 2.14 & 19.76 & 120 & 33 & 1 \\
\hline N7 & 4700 & 0 & 0 & 217 & 11 & 12 & 2.04 & 18.72 & 110 & 15 & 3 \\
\hline N7 & 7200 & 1 & 5 & 208 & 13 & 10 & 2 & 16.64 & 100 & 39 & 2 \\
\hline N7 & 7800 & 0 & 0 & 184 & 17 & 6 & 1.57 & 14.56 & 110 & 20 & 0 \\
\hline N8 & 7500 & 0 & 0 & 141 & 13 & 7 & 2.28 & 14.56 & 110 & 18 & 1 \\
\hline N8 & 6500 & 0 & 0 & 109 & 12 & 4 & 2.61 & 12.48 & 110 & 17 & 0 \\
\hline N8 & 2100 & 0 & 0 & 121 & 10 & 2 & 2.38 & 18.72 & 80 & 22 & 0 \\
\hline N8 & 2700 & 1 & 2 & 115 & 16 & 1 & 2.47 & 19.76 & 80 & 36 & 1 \\
\hline N9 & 6500 & 1 & 3 & 206 & 6 & 7 & 2.23 & 10.4 & 60 & 28 & 1 \\
\hline N9 & 5500 & 0 & 0 & 109 & 11 & 7 & 2.14 & 12.48 & 70 & 19 & 0 \\
\hline
\end{tabular}


Appendix 2 - Data on bare-face tamarin (S. bicolor) group size and the forest structure components in Central Amazon forest.

\begin{tabular}{|c|c|c|c|c|c|c|c|c|c|c|}
\hline$\overline{\text { Trail }}$ & Position & Group size & Trees & Logs & Snags & Leaf litter & Canopy opening & Altitude & Lianas & Trees and lianas fruiting \\
\hline $\mathrm{L} 1$ & 2430 & 4 & 165 & 9 & 15 & 2 & 11.44 & 120 & 25 & 3 \\
\hline L1 & 6500 & 3 & 187 & 10 & 4 & 2.47 & 20.8 & 90 & 29 & 2 \\
\hline L2 & 5900 & 4 & 121 & 14 & 2 & 2.42 & 19.76 & 120 & 22 & 1 \\
\hline L2 & 950 & 10 & 160 & 12 & 4 & 2.66 & 9.35 & 120 & 17 & 0 \\
\hline L2 & 7500 & 5 & 162 & 15 & 2 & 2.19 & 17.68 & 60 & 21 & 2 \\
\hline L3 & 1920 & 2 & 133 & 6 & 6 & 1 & 14.56 & 40 & 11 & 1 \\
\hline L3 & 4850 & 3 & 168 & 3 & 7 & 2 & 10.4 & 120 & 28 & 1 \\
\hline L3 & 3100 & 5 & 138 & 8 & 13 & 2.38 & 15.6 & 80 & 49 & 1 \\
\hline L3 & 2200 & 6 & 166 & 4 & 7 & 2.52 & 12.48 & 60 & 12 & 1 \\
\hline L4 & 2650 & 4 & 142 & 6 & 7 & 2.33 & 13.52 & 90 & 13 & 1 \\
\hline L5 & 3700 & 3 & 134 & 4 & 4 & 2.66 & 9.35 & 120 & 37 & 1 \\
\hline L6 & 4800 & 2 & 152 & 13 & 8 & 1.75 & 16.64 & 90 & 68 & 1 \\
\hline L6 & 3500 & 7 & 112 & 17 & 10 & 2 & 20.8 & 120 & 26 & 0 \\
\hline L7 & 5400 & 6 & 151 & 14 & 11 & 2.42 & 14.56 & 120 & 30 & 2 \\
\hline L7 & 2970 & 11 & 161 & 5 & 6 & 2.04 & 9.35 & 140 & 23 & 1 \\
\hline L7 & 2500 & 8 & 94 & 21 & 14 & 1.95 & 19.76 & 100 & 20 & 1 \\
\hline L8 & 1250 & 5 & 125 & 6 & 4 & 2 & 10.4 & 60 & 29 & 2 \\
\hline L8 & 3300 & 7 & 117 & 15 & 0 & 2.23 & 19.76 & 80 & 21 & 4 \\
\hline L8 & 160 & 7 & 134 & 6 & 5 & 2.42 & 12.48 & 60 & 23 & 1 \\
\hline L8 & 700 & 6 & 105 & 12 & 7 & 2.19 & 19.76 & 60 & 64 & 2 \\
\hline L8 & 6500 & 4 & 185 & 14 & 11 & 2.04 & 12.48 & 80 & 42 & 4 \\
\hline L8 & 5600 & 7 & 211 & 11 & 5 & 1.61 & 17.68 & 120 & 31 & 0 \\
\hline L8 & 5100 & 5 & 221 & 14 & 9 & 1.52 & 23.92 & 110 & 38 & 4 \\
\hline N1 & 3200 & 9 & 141 & 4 & 4 & 2 & 14.56 & 40 & 18 & 1 \\
\hline $\mathrm{N} 1$ & 1000 & 3 & 149 & 7 & 5 & 1 & 13.52 & 80 & 23 & 2 \\
\hline N1 & 7300 & 3 & 158 & 4 & 6 & 1.04 & 11.44 & 80 & 20 & 2 \\
\hline N2 & 160 & 4 & 148 & 5 & 13 & 2.09 & 13.52 & 120 & 8 & 0 \\
\hline N2 & 1900 & 5 & 98 & 11 & 3 & 2 & 20.8 & 80 & 19 & 0 \\
\hline N3 & 3700 & 3 & 158 & 6 & 5 & 1.33 & 10.4 & 80 & 28 & 1 \\
\hline N3 & 6200 & 5 & 139 & 4 & 6 & 1.76 & 12.48 & 80 & 18 & 2 \\
\hline N3 & 2900 & 5 & 153 & 10 & 5 & 2.33 & 10.4 & 100 & 25 & 0 \\
\hline N4 & 3800 & 6 & 147 & 4 & 5 & 2.28 & 13.52 & 100 & 20 & 4 \\
\hline N4 & 4600 & 8 & 118 & 17 & 2 & 2.66 & 18.72 & 80 & 18 & 3 \\
\hline N4 & 1500 & 3 & 135 & 9 & 11 & 2.19 & 14.56 & 80 & 12 & 1 \\
\hline N5 & 2920 & 5 & 162 & 4 & 9 & 2.14 & 14.56 & 120 & 21 & 2 \\
\hline N5 & 3400 & 4 & 112 & 9 & 2 & 1.38 & 43.68 & 120 & 20 & 0 \\
\hline N5 & 5500 & 6 & 197 & 18 & 8 & 2.04 & 20.8 & 120 & 18 & 0 \\
\hline N7 & 5500 & 7 & 203 & 15 & 10 & 2.14 & 19.76 & 120 & 33 & 1 \\
\hline N7 & 7200 & 5 & 208 & 13 & 10 & 2 & 16.64 & 100 & 39 & 2 \\
\hline N8 & 2700 & 2 & 115 & 16 & 1 & 2.47 & 19.76 & 80 & 36 & 1 \\
\hline N9 & 6500 & 3 & 206 & 6 & 7 & 2.23 & 10.4 & 60 & 28 & 1 \\
\hline
\end{tabular}


Appendix 3 - Data on bare-face tamarin (S. bicolor) group densities and the forest structure components in Central Amazon forest.

\begin{tabular}{|c|c|c|c|c|c|c|c|c|c|}
\hline Blocks & Density & Trees & Logs & Snags & Leaf litter & Canopy opening & Altitude & Lianas & Trees and lianas fruiting \\
\hline 1 & 4 & 138.75 & 8.75 & 6.25 & 1.9 & 14.3 & 100 & 16.75 & 0.5 \\
\hline 2 & 3 & 146 & 8.66 & 13 & 2.1 & 13.8 & 93.3 & 28.6 & 1.6 \\
\hline 3 & 2 & 144.5 & 8.5 & 4.5 & 2.2 & 15.08 & 120 & 25 & 1 \\
\hline 4 & 2 & 174.5 & 12.5 & 3 & 2.3 & 19.24 & 75 & 25 & 2 \\
\hline 5 & 4 & 146.25 & 6.5 & 5 & 1.6 & 12.48 & 65 & 20.5 & 0.75 \\
\hline 6 & 3 & 133.6 & 6.33 & 4.6 & 1.9 & 23.5 & 103.3 & 17.6 & 1.6 \\
\hline 7 & 0 & 159 & 10 & 3 & 2.1 & 18.72 & 90 & 44 & 1 \\
\hline 8 & 1 & 115 & 16 & 1 & 2.4 & 19.76 & 80 & 36 & 1 \\
\hline 9 & 0 & 180 & 8 & 2 & 2.0 & 23.92 & 90 & 25 & 1 \\
\hline 10 & 4 & 131.25 & 10.75 & 5.5 & 2.3 & 14.56 & 115 & 26 & 1.25 \\
\hline 11 & 3 & 184 & 15.33 & 8.6 & 1.9 & 19.0 & 110 & 39.6 & 0.6 \\
\hline 12 & 0 & 159.5 & 10.5 & 9 & 1.7 & 19.76 & 95 & 16.5 & 1.5 \\
\hline 14 & 3 & 111 & 16 & 7.3 & 2.0 & 20.1 & 80 & 19.6 & 2 \\
\hline 15 & 5 & 181.6 & 14.2 & 9.4 & 2.0 & 17.68 & 116 & 31.8 & 1.6 \\
\hline 16 & 3 & 200.3 & 10 & 9.66 & 1.8 & 16.64 & 86.6 & 28 & 2.6 \\
\hline
\end{tabular}

